\title{
DNA barcoding techniques used to identify the shared ichthyofauna between the Pantanal floodplain and Upper Parana River
}

\section{Guilherme J. da Costa-Silva, Fernando Yuldi Ashikaga, Cristiane Kioko Shimabukuro Dias, Luiz Henrique Garcia Pereira, Fausto Foresti \& Claudio Oliveira}

To cite this article: Guilherme J. da Costa-Silva, Fernando Yuldi Ashikaga, Cristiane Kioko Shimabukuro Dias, Luiz Henrique Garcia Pereira, Fausto Foresti \& Claudio Oliveira (2018) DNA barcoding techniques used to identify the shared ichthyofauna between the Pantanal floodplain and Upper Parana River, Mitochondrial DNA Part A, 29:7, 1063-1072, DOI: 10.1080/24701394.2017.1404046

To link to this article: https://doi.org/10.1080/24701394.2017.1404046

曲 Published online: 20 Nov 2017.

Submit your article to this journal $₫$

III Article views: 93

Q View related articles $\widetilde{ }$

View Crossmark data $\asymp$ 


\title{
DNA barcoding techniques used to identify the shared ichthyofauna between the Pantanal floodplain and Upper Parana River
}

\author{
Guilherme J. da Costa-Silva ${ }^{a *}$, Fernando Yuldi Ashikaga ${ }^{a *}$, Cristiane Kioko Shimabukuro Dias ${ }^{a}$, \\ Luiz Henrique Garcia Pereira ${ }^{b}$, Fausto Foresti ${ }^{a}$ and Claudio Oliveira ${ }^{a}$

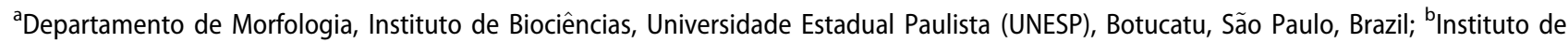 \\ Ciências da Vida e da Natureza, Universidade Federal da Integração Latino-Americana (UNILA), Foz do Iguaçu, Paraná, Brazil
}

\begin{abstract}
The biological invasion process is widely debated topic, as the population depletion of some species and the extinction of others are related to this process. To accelerate the identification of species and to detect non-native forms, new tools are being developed, such as those based on genetic markers. This study aimed to use Barcode DNA methodology to identify fish species that had translocated between the Parana and Paraguay River Basins. Based on a database of two studies that were conducted in these regions, 289 sequences of Cytochrome Oxidase C subunit 1 (COI) were used for General Mixed Youle Coalecent (GMYC) analysis, including 29 morphospecies that were sampled in both river basins. As a result, we observed that while some morphospecies have low variation, demonstrating a recent occupation of the basins, other morphospecies probably represent species complexes. A third of the morphospecies had well-defined lineages but not enough to be treated as different Molecular Operational Taxonomic Units (MOTUs). These results demonstrate that human interventions possibly participated in the distribution of some lineages. However, biogeographical historical processes are also important for the morphospecies distribution. The data suggest that the number of species that are present in these two basins is underestimated and that human actions can irreversibly affect the natural history of the species in these regions.
\end{abstract}

\section{ARTICLE HISTORY}

Received 16 August 2017

Accepted 8 November 2017

\section{KEYWORDS}

DNA barcoding; cytochrome oxidase 1; neotropical species; Pantanal; Upper

Parana River

\section{Introduction}

In recent decades, the introduction of non-native species has generated many discussions; however, the process of 'biological invasion' had already registered its effects long ago, being reported as the second leading cause of extinction, behind only environmental changes (Simberloff 2009; Simberloff et al. 2013; Pelicice et al. 2014). Although the processes of extinction and biological invasions are natural events, human actions have intensified them in recent years, becoming a major problem for the functionality of ecosystems and affecting the main types of ecological relations (predation, competition, herbivory, parasitism and mutualism) (Fuller et al. 1999).

The Pantanal and the Upper Parana River floodplains are drained by two major rivers of the La Plata Basin: the Paraguay and Parana Rivers. These two ecoregions have several characteristics in common, such as seasonally flooded areas and rich biodiversity, and both suffer from anthropic effects (Agostinho and Zalewski 1996; Agostinho et al. 2005; Britton and Orsi 2012).

The vast area of the La Plata Basin (1.4 million $\mathrm{km}^{2}$ ) is reflected in its rich diversity of fish. This richness of species is unevenly distributed, and many of the rivers that form this basin have no connections that allow migration flow (Petrere et al. 2002; Langeani et al. 2007; Ferreira et al. 2009; Polaz et al. 2014). The La Plata basin can be divided in two main portions: the upper Paraná and the lower Paraná plus the Paraguay River. Each of these portions is distinguished by high levels of fish fauna endemism (Britski et al. 1999; Langeani et al. 2007) due the approximately 100-m-high barrier of the Sete Quedas waterfalls. After the construction of the Itaipu Power Plant, the natural barriers of Sete Quedas were submerged; thus, the ichthyofauna interchange between the Upper Paraná and the remainder of the La Plata Basin is increasingly reported (Langeani et al. 2007; Ferreira et al. 2009; Buckup 2011).

The breaking of natural barriers, the deliberate introduction of species into these environments for sport fishing, aquaculture, ornamental fish breeding and the inadequate management of wild populations are the most frequent causes of exotic species introduction (Agostinho et al. 2005; Pelicice et al. 2014). Thus, geographically isolated rivers now share species with other rivers, being main the main agent of this introduction process (Britton and Orsi 2012).

CONTACT Fernando Yuldi Ashikaga fyuldi@gmail.com @ Departamento de Morfologia, Instituto de Biociências, Universidade Estadual Paulista (UNESP), Botucatu, São Paulo, Brazil

*These authors contributed equally to this work.

(4) Supplemental data for this article can be accessed here.

(C) 2017 Informa UK Limited, trading as Taylor \& Francis Group 
Studies by Langeani et al. (2007) and Júlio Júnior et al. (Ferreira et al. 2009), based on morphological identification, characterized the Upper Paraná ichthyofauna and identified the presence of putative non-native species from regions of the Lower Parana River and the Paraguay River. The identification of non-native species is an important step for the conservation of an ecosystem, generating sufficient information to propose actions for management and supervision to prevent new introductions. In this context, the recent DNA barcoding methodology (Hebert et al. 2003) has proven to be a valuable genetic tool for the rapid and accurate identification of species, being that many studies have been published demonstrating its effectiveness in identifying fish species (Holmes et al. 2009; Ward 2009; Pereira et al. 2013). DNA barcodes, in association with probabilistic analyses, have acquired efficiency and lost subjectivity, becoming an interesting start point for taxonomic studies (Kekkonen and Hebert 2014). Pereira et al. (2013) and Shimabukuro-Dias et al. (2016, in press) used this methodology to perform molecular identification studies of the fish fauna from the Upper Parana River and Paraguay River (Pantanal National Park), respectively.

The aim of this study was to conduct a comparative molecular survey of fish species from the Pantanal and Upper Parana River Flood Basin to identify the translocation of species between these two biomes using a molecular identification methodology: DNA barcoding.

\section{Material and methods}

In the present work, we used sequences of the gene Cytochrome oxidase C subunit I (COI) of 29 morphospecies (species were identified by morphological characters) that were shared by the Upper Parana River and the Paraguay River, available in ((Pereira et al. 2013) and (Shimabukuro-Dias et al. 2016)) (S1 Table). A total of 289 sequences ranging between 450 and 660 bases pairs were analyzed. Vouchers of all the specimens that were analyzed are deposited at the Laboratório de Biologia e Genética de Peixes (LBP), and details of each specimen and their sequence accessions are available in S1 Table.

\section{Sequence alignment and genetic divergence analysis}

All of the COI sequences were aligned using MUSCLE (Edgar 2004) following the default parameters. The final matrix was defined after a manual correction of the misalignment by GENEIOUS (Drummond et al. 2011). The pairwise distance between all of the sequences was determined by MEGA 6 (Tamura et al. 2013) with the K2P nucleotide evolutionary model.

\section{Molecular species definition}

We used the GMYC analysis to determine the threshold time between the Yule and coalescent processes. This threshold is defined as a shift point in the rate of the cladogenetic process in an ultrametric tree (Pons et al. 2006;
Monaghan et al. 2009). The ultrametric tree was generated by Bayesian Phylogenetic reconstruction in BEAST (Drummond and Rambaut 2007). The relaxed lognormal distribution and the Birth and Death process as tree priors were used as clock models. The GTR model was used as nucleotide evolution model, and the Markov Chain (MCMC) procedure was used with $30 \times 10^{6}$ generations, sampling one tree every $10^{4}$ generations. The tree with the most credibility nodes was selected in TREEANNOTATOR, used as the ultrametric tree, and submitted for GMYC analysis in R (R Development Core Team 2013) with the splits package and a single threshold using default parameters.

We divided the morphospecies into three categories (the criteria for category distinction are shown graphically in Figure 1): (A) species complex: when a morphospecies has more than one Molecular Operational Taxonomic Unit (MOTU); (B) species with low genetic variation but with wide distribution; and (C) morphospecies with populations under advanced speciation. The morphospecies of category $C$ have populations with high genetic divergence but in which the variation of the basal node of the group crosses the threshold time.

\section{Results}

After alignment and edition, one matrix with 506 characters (238 variables and only one singleton) was obtained. The overall genetic distance was $24 \%$, and the means of the distances between morphospecies was $1.5 \%$. The nucleotide composition of the matrix was $24.1 \%$ adenine, $28.2 \%$ cytosine, $29.9 \%$ thymine and $17.9 \%$ guanine. No insertions, deletions or stop-codons were detected.

The GMYC analysis resulted in a threshold time of -0.008288871 (arbitrary scale ranging from 0 to -8 before present) and 43 MOTUs (confidence interval of 39-45). All of the morphospecies were genetically distinguishable. The species Lepthoplosternum pectorale, Gymnotus inaequilabiatus, Parodon nasus, Piaractus mesopotamicus, Leporinus friderici, Leporinus lacustris, Auchenipterus osteomystax, Pseudoplatystoma corruscans, Pinirampus pirinampu, Potamotrygon amandae, Crenicichla lepidota, Hyphessobrycon eques, Moenkhausia forestii, Roeboides paranensis, Gymnocorymbus ternetzi and Psellogrammus kennedyi presented only one MOTU with low genetic variation (pattern A in Figure 1). Pyrrhulina australis, Iheringichthys labrosus and Leporinus macrocephalus presented only one MOTU but had great genetic variation (pattern C of Figure 1). The morphospecies Synbranchus marmoratus, Rhamdia quelen, Leporinus striatus, Hoplias malabaricus, Eigenmannia virescens, Eigenmannia trilineata, Sternopygus macrurus, Pimelodus maculatus and Brachyhypopomus pinnicaudatus showed more than one MOTU each (pattern B of the Figure 1), and these MOTUs were sampled exclusively in one river system (except by one MOTU of Brachyhypopomus pinnicaudatus, which was distributed in both river systems) (Figure 2). The morphospecies Synbranchus marmoratus, Eigenmannia trilineata and Brachyhypopomus pinnicaudatus showed more than one MOTU in the same river system (Paraguay or Upper Parana) (Figure 2), and details of the genetic variations between MOTUs are shown in Table 1 . 


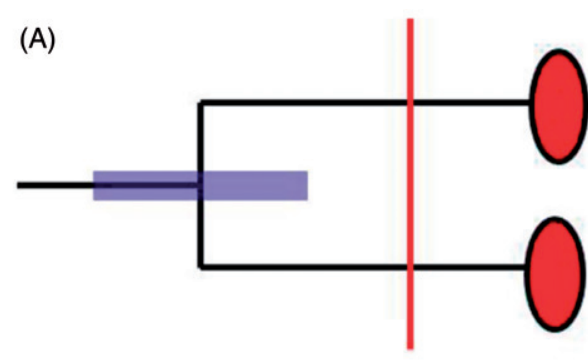

(घ)

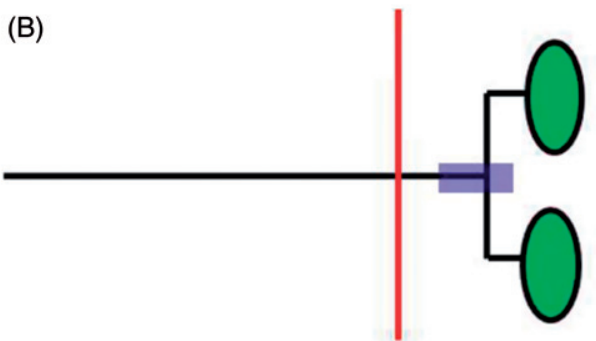

(C)
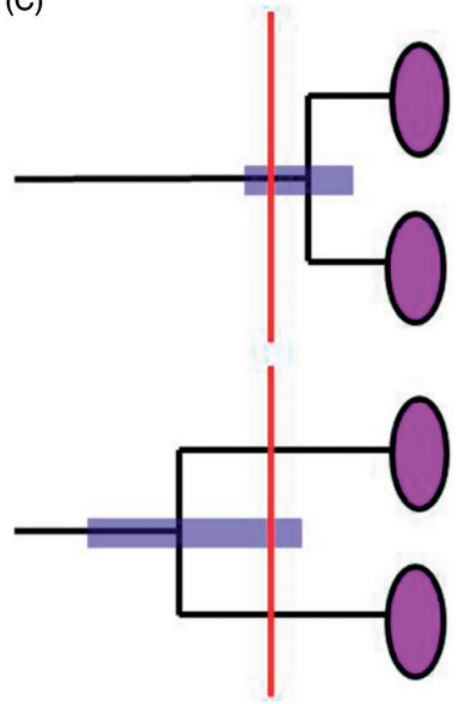

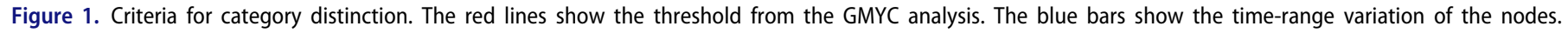

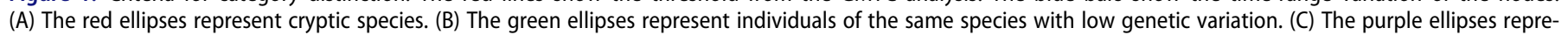
sent individuals of the same species but undergoing speciation. In this last case, the variation of the nodes crosses the threshold of the GMYC analysis.

\section{Discussion}

\section{Low genetic variation among populations}

Since the 1970s, the occurrence of ichthyological interchange between the Upper Paraná River system and Paraguay River system has been reported, mainly due to inundation by Itaipu Lake and the construction of a water channel to enable fish passage between the Lower and Upper Parana River (Langeani et al. 2007; Ferreira et al. 2009). According to Langeani et al. (2007), the transplant of 37 species has been registered. Additionally, other human activities, such as aquaculture and fisheries, have also been reported as responsible for fish introduction, and these activities have promoted the sharing of 67 species between the two ecosystems (Langeani et al. 2007). In this way, it is expected that the species that were transplanted by human activities do not show deep genetic differences between populations due to the small time interval. This pattern was found in several species (pattern B in Figure 1), such as Leporinus friderici, Leporinus lacustris, Auchenipterus osteomystax, Hyphessobrycon eques, Lepthoplosternum pectorale, Moenkhausia forestii (possibly called "M. sanctaefilomenae" in (Langeani et al. 2007)), Parodon nasus, Piaractus mesopotamicus, Pinirampus pirinampu, Pseudoplatystoma corruscans, Loricariichthys platymetopon, Roeboides descalvadensis, Potamotrygon amandae (called 'P. motoro' in Langeani et al. 2007), which were probably introduced due to the construction of the Itaipu Dam (Langeani et al. 2007), while Gymnocorymbus ternetzi could have originated by aquaculture release and Brachyhypopomus pinnicaudatus and Gymnotus inaequilabiatus by fishery activities (Langeani et al. 2007). Here, Psellogrammus kennedyi and Crenicichla lepidota were detected in both systems for the first time. Considering that these species do not have great fishing or aquarist appeals, it is probable that their distribution was promoted by Itaipu interference.

\section{Cryptic species}

Langeani et al. (2007) estimated that at least 50 species are taxonomically undescribed in the Upper Paraná River system. These species show low levels of gene flow between populations, hampered by the habitat's discontinuation; thus, there is a high probability of allopatric speciation (Langeani et al. 2007). Here, we identified 19 putative new species (pattern A in Figure 1), being that only the Hoplias malabaricus complex had been previously reported (Langeani et al. 2007). All of the species that were analyzed inhabit the main drainage of the rivers, with a huge water volume and predominantly slow flow. This habitat is generally continuous, and the absence of a barrier allows local species to transit across the river, enabling genetic homogeneity (Ashikaga et al. 2015). Thus, under environmental continuity, where in theory there is a high permittivity of gene flow, the new finding of cryptic species leads us to believe that the previous estimate of the number of fish species occurring in this region is an underestimate.

The Upper Parana ecoregion was separated from the Pantanal (Paraguay River) by the Sete Quedas waterfalls (today inundated by Itaipu Lake) during the late Miocene and Pliocene (Lima and Moreira 2003). More recent events of Neotectonic reactivations have caused headwater stream captures in the boundary of the Upper Paraná and Paraguay basins (Menezes et al. 2008; Brea and Zucol 2011) and have permitted fish interchange between these regions (Menezes et al. 2008). These events show a complex biogeographical scenario of the La Plata basin and could be a vicarious process responsible for the deep genetic segregation and consequent allopatric speciation in the resident ichthyofauna. This hypothesis could explain cases such as Hoplias malabaricus, Rhamdia quelen, Leporinus striatus and Pimelodus maculatus, where cryptic species are apparently exclusive to each river system. However, species such as Synbranchus marmoratus, 


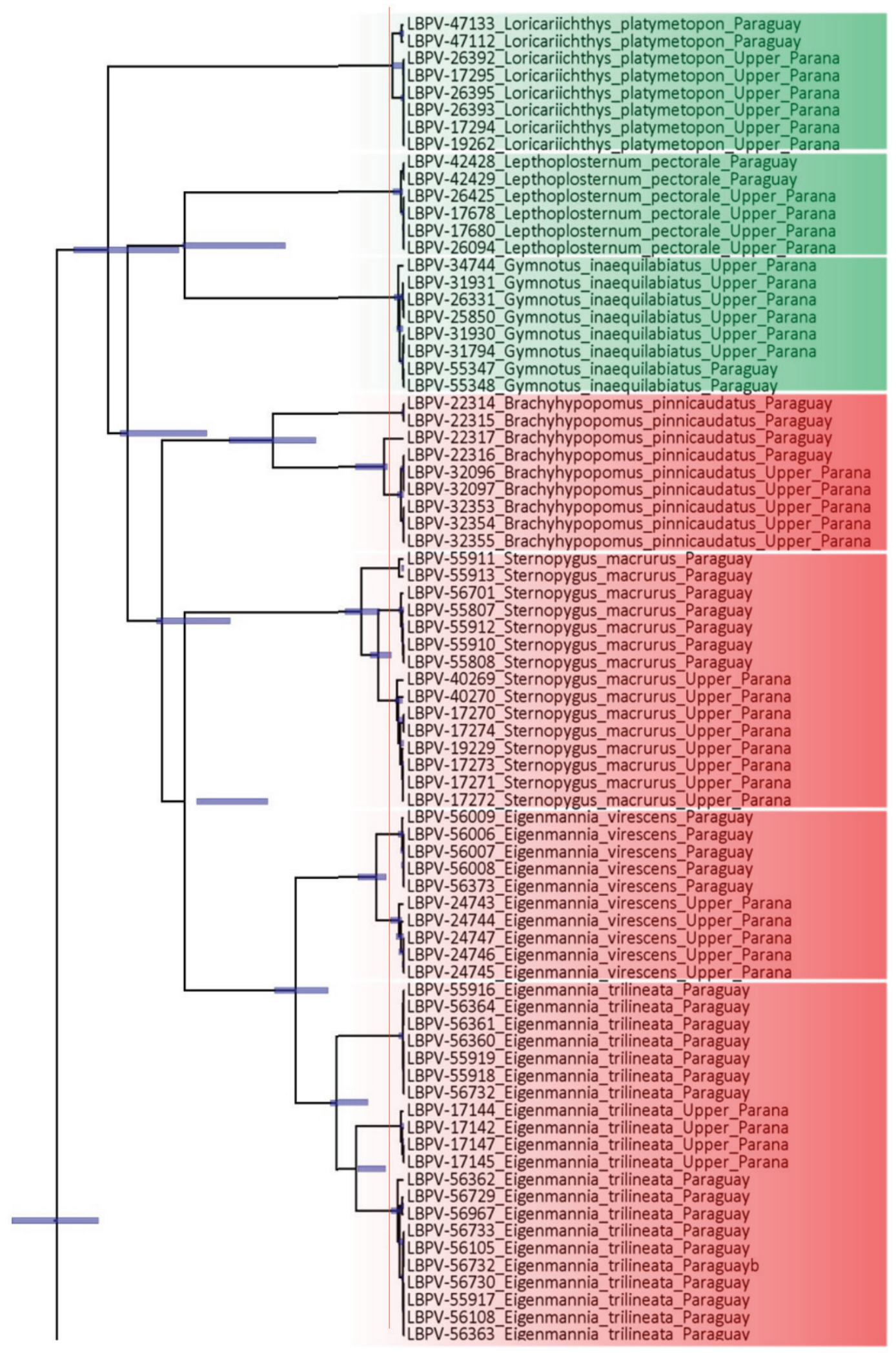

Figure 2. Ultrametric tree of the shared species between Upper Paraná and Paraguay River basins. The red line shows the threshold of the GMYC analysis; the blue bars represent the variances of the nodes (95\%); the red boxes represent cryptic species (pattern A in Figure 1); the green boxes represent individuals of the same species with low genetic variation (pattern B in Figure 1); and the purple boxes represent individuals of the same species under speciation process (pattern C in Figure 1). 


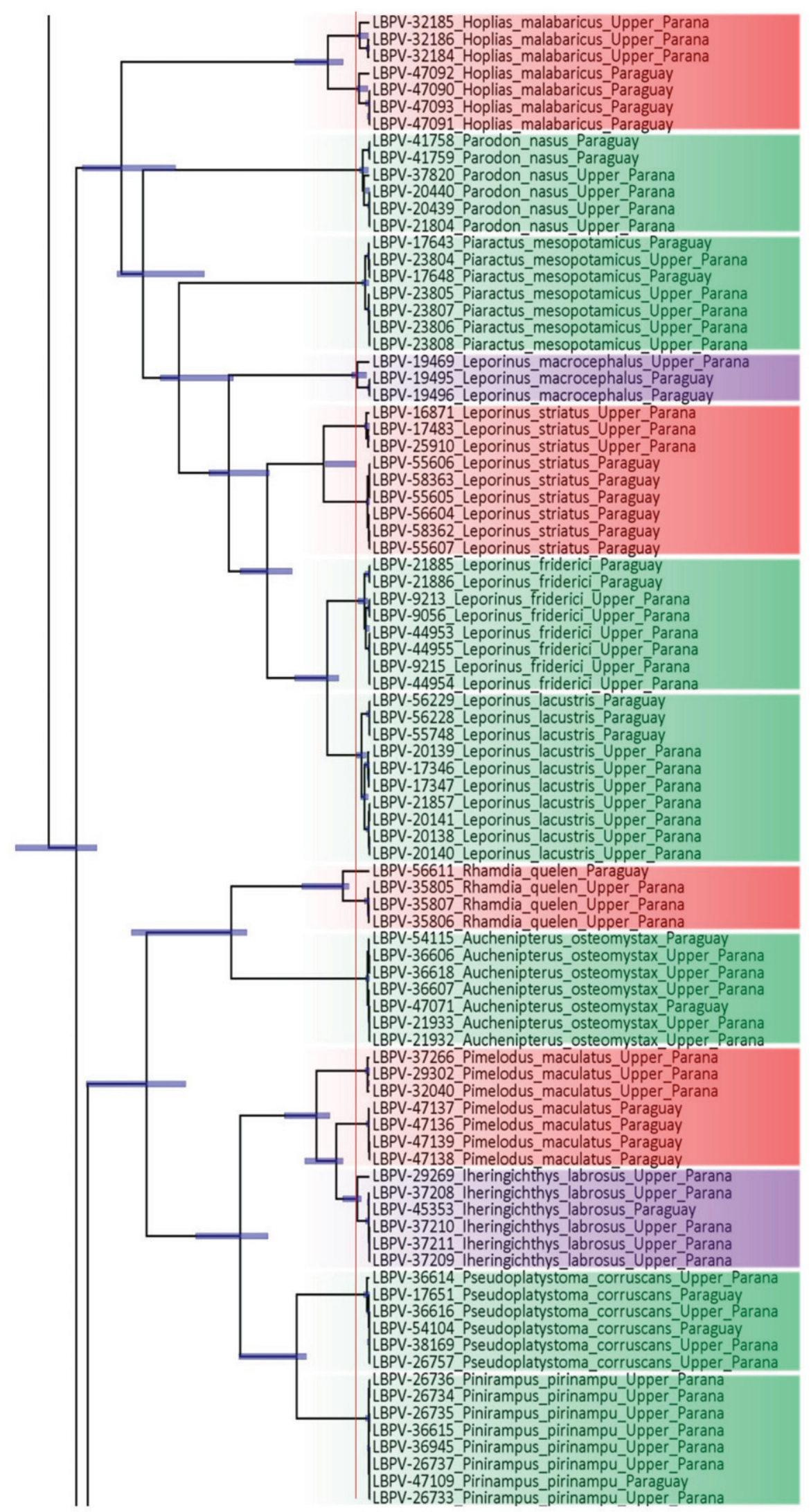

Figure 2. Continued. 


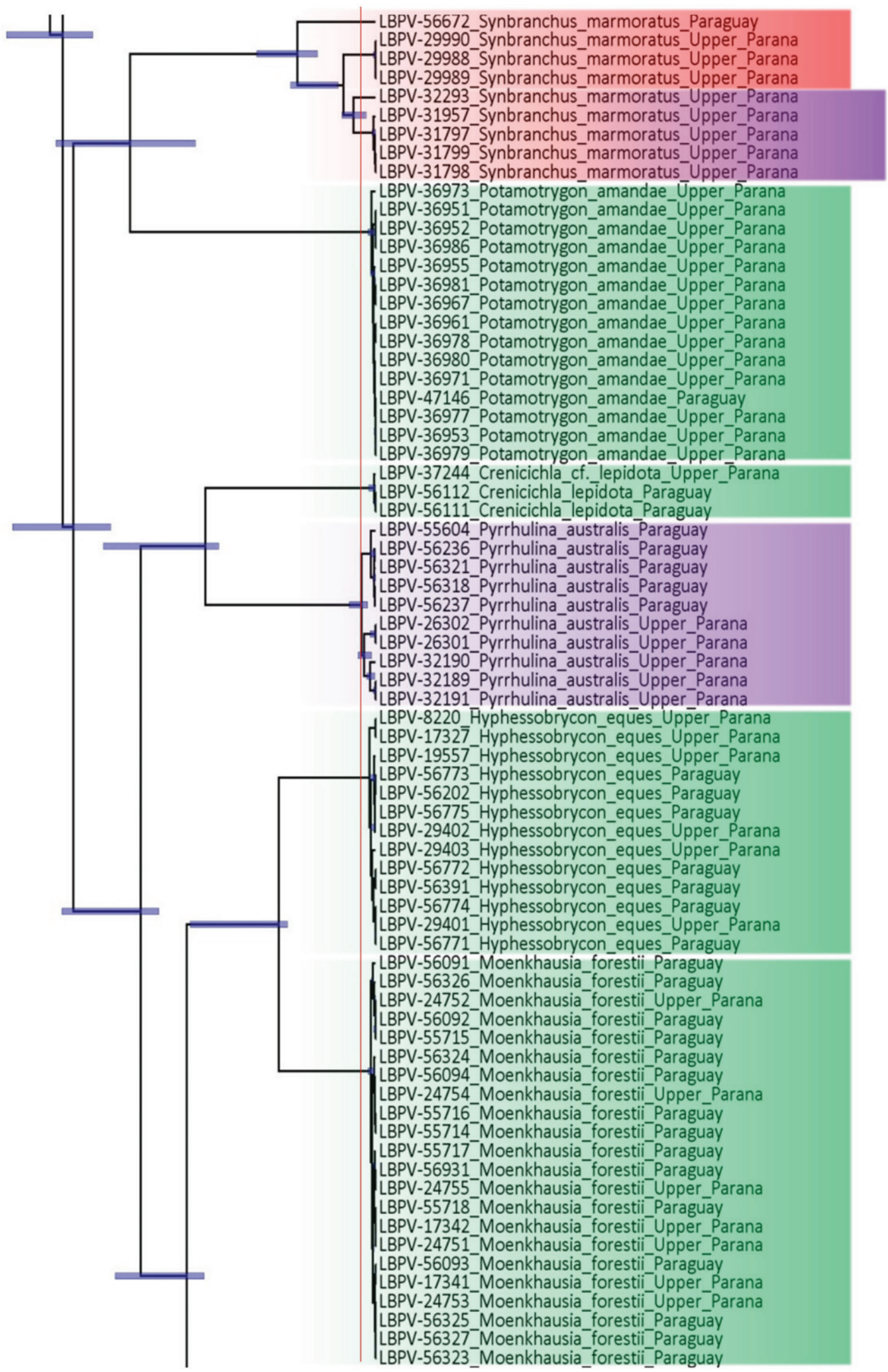

Figure 2. Continued. 


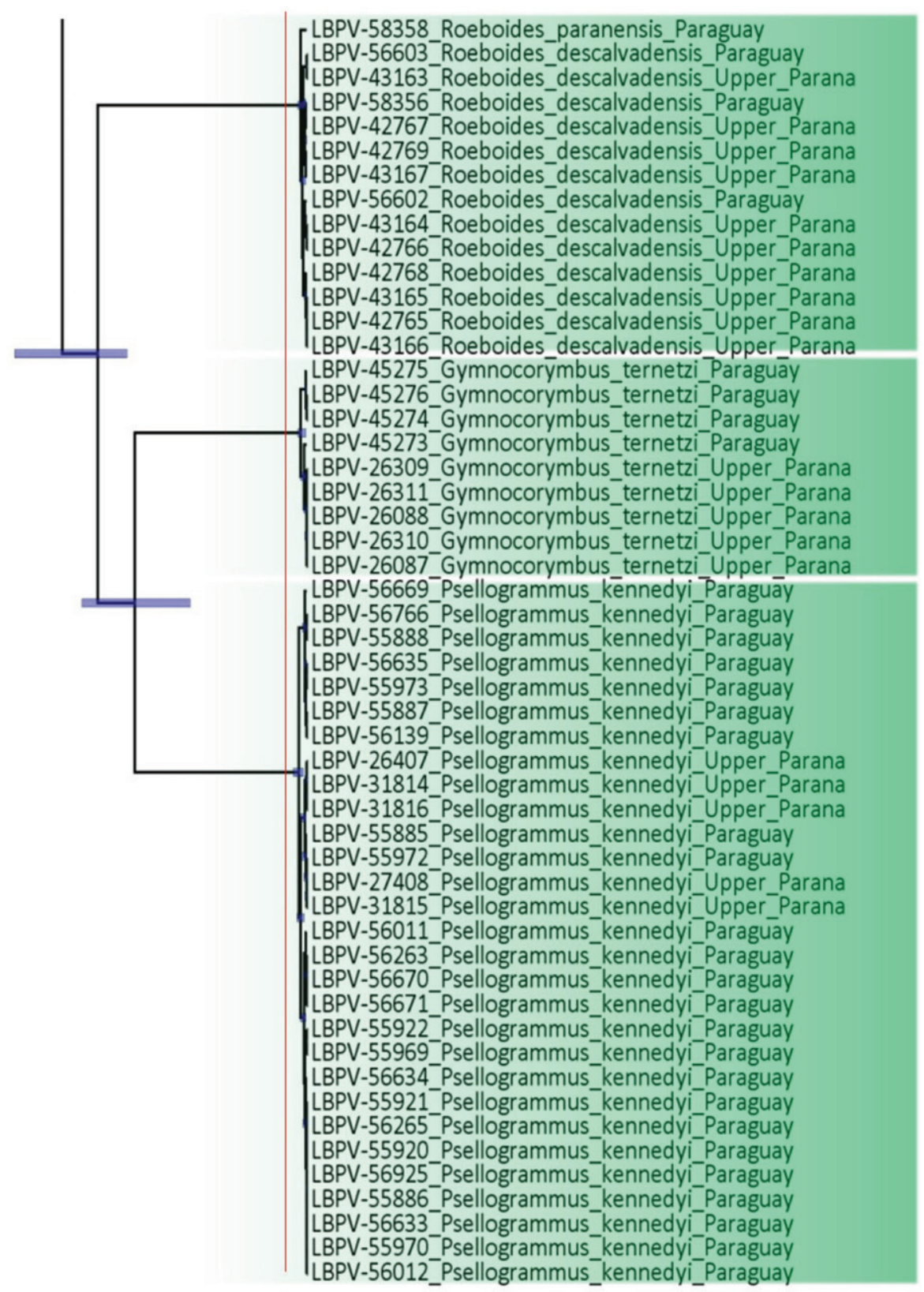

Figure 2. Continued.

Sternopygus macrurus, Eigenmannia virescens, E. trilineata and Brachyhypopomus pinnicaudatus are complexes with more than two cryptic species each, coexisting in the same river basin. The fact that more than one entity has a natural distribution overlap is a strong indication of reproductive isolation among these entities (Kekkonen and Hebert 2014) and that they consequently could be considered distinct species (since Mayr 1940).

Other studies have reported that Hoplias malabaricus (Utsunomia et al. 2014a), Synbranchus marmoratus (Torres et al. 2005; Utsunomia et al. 2014b), Rhamdia quelen (Martinez et al. 2011), Sternopygus macrurus (de AlmeidaToledo et al. 1993), Eigenmannia virescens (Silva et al. 2009), E. trilineata (Moysés et al. 2010) and Brachyhypopomus pinnicaudatus (Giora 2009) are species complexes, but this is the first time that Leporinus striatus and Pimelodus maculatus are listed as putative species complexes.

Leporinus striatus is a morphospecies with a very wide distribution in cis- and trans-Andean regions, and this distribution probably precedes the uplift of the Andes that occurred approximately 12 million years ago (Albert et al. 2006). However, the old separation of the groups leaves doubt regarding the possibility of natural genetic flow between the species. Leporinus striatus was revised in (Birindelli and Britski 2013), and in that study, no morphological differentiations were detected. In the present work, the deep genetic divergence $(4.4 \%)$ between specimens that were sampled from the Upper Parana and Paraguay Rivers provides a strong 
$1070-$ G. J. DA COSTA-SILVA ET AL.

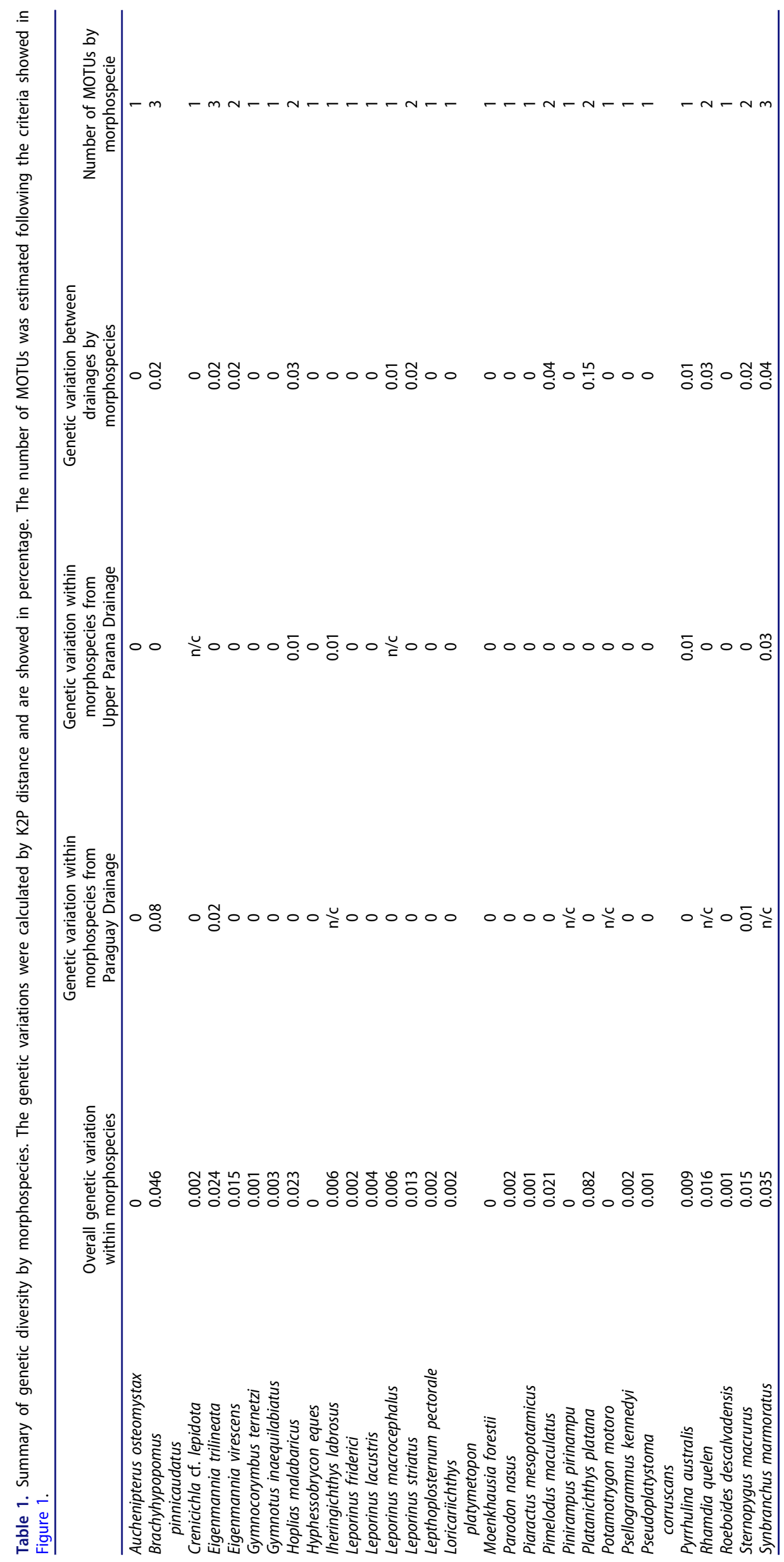


argument to propose the existence of more than one taxon, and the maintenance of these morphological characteristics could be a reflex of adaptations to specific types of habitats.

Although Pimelodus maculatus has an estimated distribution from the Parana River Basin to the San Francisco River Basin (Reis et al. 2003) and does not show morphological characteristics that differentiate between localities of occurrence (Lundberg et al. 2011), specimens of the Upper Parana and Pantanal Rivers showed a genetic divergence of $6.6 \%$, which may represent a recent speciation event leading to the emergence of a species complex.

\section{Speciation processes}

To avoid an overestimation of the number of MOTUs, we adopted a conservative position, given that when the variation of the basal nodes of the entities (pattern $C$ of Figure 1) crosses the threshold from the GMYC analyses, these groups are threatened as single species but are in an advanced stage of the speciation process. In Leporinus macrocephalus and Pyrrhulina australis, the haplogroups that are present are apparently exclusive to each locale (Figure 2), suggesting that the genetic divergence between specimens of the two localities is due to the evolutionary life history of the species, as anthropic activity would not have had enough time to produce such a pronounced genetic differentiation.

The same genetic pattern was found in Iheringichthys labrosus, but although this species presented two well-defined haplogroups, one of these haplogroups was shared in both river basins. This fact is interesting because if reproductive isolation were not established, it is possible that gene flow between haplogroups may interfere with the natural evolutionary course of this specie and other species sharing the same pattern.

\section{Disclosure statement}

No potential conflict of interest was reported by the authors.

\section{References}

Agostinho AA, Thomaz SM, Gomes LC. 2005. Conservation of the biodiversity of Brazil's Inland waters. Conserv Biol. 19:646-652.

Agostinho AA, Zalewski M. 1996. A planície alagável do alto rio Paraná: importância e preservação. Brazil: Eduem, Maringá, 100 p.

Albert JS, Lovejoy NR, Crampton WGR. 2006. Miocene tectonism and the separation of cis- and trans-Andean river basins: evidence from Neotropical fishes. J South Am Earth Sci. 21:14-27.

Ashikaga FY, Orsi ML, Oliveira C, Senhorini JA, Foresti F. 2015. The endangered species Brycon orbignyanus: genetic analysis and definition of priority areas for conservation. Environ Biol Fishes. 98:1845-1855.

Birindelli JLO, Britski HA. 2013. Two new species of Leporinus (Characiformes: Anostomidae) from the Brazilian Amazon, and redescription of Leporinus striatus Kner 1858. J Fish Biol. 83:1128-1160.

Brea M, Zucol AF. 2011. The Paraná-Paraguay Basin: Geology and Paleoenvironments. In: Albert JS, Reis RE editors. Los Angeles: University of California Press, pp. 69-87.

Britski HA, Silimon K, Lopes B. 1999. Peixes do Pantanal: Manual de identificação. Brasilia: Embrapa Informação Tecnológica, 184 p.

Britton JR, Orsi ML. 2012. Non-native fish in aquaculture and sport fishing in Brazil: economic benefits versus risks to fish diversity in the upper River Paraná Basin. Rev Fish Biol Fisheries 22:555-565.
Buckup PA. 2011. The Eastern Brazilian Shield. Historical Biogeography of Neotropical Freshwater Fishes: 203-210.

de Almeida-Toledo LF, Foresti F, Daniel MFZ, de Almeida Toledo-Filho S. 1993. Nucleolar chromosome variants in Sternopygus macrurus (Pisces, Sternopygidae) from three Brazilian river basins. Caryologia. 46:53-61.

Drummond AJ, Ashton B, Buxton S, Cheung M, Cooper A, Duran C, Field M, Heled J, Kearse M, Markowitz S, et al. 2011. Geneious v5.4.

Drummond AJ, Rambaut A. 2007. BEAST: Bayesian evolutionary analysis by sampling trees. BMC Evol Biol. 7:214

Edgar RC. 2004. MUSCLE: a multiple sequence alignment method with reduced time and space complexity. BMC Bioinformatics. 5:113.

Ferreira H, Júnior J, Tós CD, Agostinho ÂA, Pavanelli CS. 2009. A massive invasion of fish species after eliminating a natural barrier in the upper Rio Paraná basin. Neotrop Ichthyol. 7:709-718.

Fuller PL, Nico LG, Williams JD. 1999. Nonindigenous fishes introduced into inland waters of the United States. In: M. Odeh, editor. Bethesda, USA: American Fisheries Society, pp. 469-472.

Giora J. 2009. Zootaxa, Brachyhypopomus gauderio, new species, a new example of underestimated. Zootaxa 68:60-68.

Hebert PD, Ratnasingham S, DeWaard JR. 2003. Barcoding animal life: cytochrome $C$ oxidase subunit 1 divergences among closely related species. Proc R Soc Lond. Ser B: Biol Sci. 270:S96.

Holmes BH, Steinke D, Ward RD. 2009. Identification of shark and ray fins using DNA barcoding. Fisheries Res. 95:280-288.

Kekkonen M, Hebert PDN. 2014. DNA barcode-based delineation of putative species: efficient start for taxonomic workflows. Mol Ecol Resources 14:706-715.

Langeani F, Castro RMC, Oyakawa OT, Shibatta O. a, Pavanelli CS, Casatti L. 2007. Diversidade da ictiofauna do Alto Rio Paraná: composição atual e perspectivas futuras. Biota Neotropica 7:1-17.

Lima FCT, Moreira CR. 2003. Three new species of Hyphessobrycon (Characiformes: Characidae) from the upper Rio Araguaia basin in Brazil. Neotropical Ichthyol. 1:21-33.

Lundberg JG, Sullivan JP, Hardman M. 2011. Phylogenetics of the South American Catfish family Pimelodidae (Teleostei: Siluriformes) using nuclear and Mitochondrial Gene sequences. Proc Acad Nat Sci Philadelphia. 61:153-189.

Martinez JF, Lui RL, Blanco DR, Traldi JB, Silva LF, Venere PC, Souza IL, Moreira-Filho O. 2011. Comparative cytogenetics of three populations from the Rhamdia quelen species complex (Siluriformes, Heptapteridae) in two Brazilian hydrographic basins. Taylor \& Francis Group. Caryologia. 64:121-128.

Mayr E. 1940. Speciation phenomena in Birds. American Naturalist 74:30. Menezes N, Ribeiro A, Weitzman S, Torres R. 2008. Biogeography of Glandulocaudinae (Teleostei: Characiformes: Characidae) revisited: phylogenetic patterns, historical geology and genetic connectivity. Zootaxa. 52:577-580.

Monaghan MT, Wild R, Elliot M, Fujisawa T, Balke M, Inward DJG, Lees DC, Ranaivosolo R, Eggleton P, Barraclough TG, et al. 2009. Accelerated species inventory on Madagascar using coalescent-based models of species delineation. System Biol. 58:298-311.

Moysés CB, Daniel-Silva M, de FZ, Lopes CE, de Almeida-Toledo LF. 2010. Cytotype-specific ISSR profiles and karyotypes in the Neotropical genus Eigenmannia (Teleostei: Gymnotiformes). Genetica. 138:179-189.

Pelicice FM, Vitule JRS, Lima Junior DP, Orsi ML, Agostinho AA. 2014. A serious new threat to Brazilian freshwater ecosystems: the naturalization of nonnative fish by Decree. Conserv Lett. 7:55-60.

Pereira LHG, Hanner R, Foresti F, Oliveira C. 2013. Can DNA barcoding accurately discriminate megadiverse Neotropical freshwater fish fauna? BMC Genetics. 14:20.

Petrere M, Agostinho AA, Okada EK, Júlio Jr. HF. 2002. Review of the fisheries in the Brazilian portion of the Paraná/Pantanal basin. In: Cowx IG, editor. Osney Mead: Fishing New Books, pp. 123-143.

Polaz CNM, Melo BF, Britzke R, de Resende EK, Machado FDA, de Lima JAF, Petrere Jr. M. 2014. Fishes from the Parque Nacional do Pantanal Matogrossense, upper Paraguai River basin, Brazil. Check List. 10:122-130.

Pons J, Barraclough TG, Gomez-Zurita J, Cardoso A, Duran DP, Hazell S, Kamoun S, Sumlin WD, Vogler AP. 2006. Sequence-based species 
delimitation for the DNA taxonomy of undescribed insects. System Biol. 55:595-609.

R Development Core Team. 2013. R Development Core Team. R: A Language and Environment for Statistical Computing.

Reis ER, Kullander SO, Ferraris CJ. 2003. Check list of the freshwater fishes of South and Central America. Porto Alegre, Brazil: EDIPUCRS, 168 p.

Shimabukuro-Dias CK, Costa Silva GJ, da Ashikaga FY, Foresti F, Oliveira C. 2016. Molecular identification of the fish fauna from the pantanal flood plain area in Brazil. Mitochondrial DNA Part A. 1394:1-5.

Silva DS, Milhomem SSR, Pieczarka JC, Nagamachi CY. 2009. Cytogenetic studies in Eigenmannia virescens (Sternopygidae, Gymnotiformes) and new inferences on the origin of sex chromosomes in the Eigenmannia genus. BMC Genetics. 10:74.

Simberloff D. 2009. The role of propagule pressure in biological invasions. Annu Rev Ecol Evol System. 40:81-102.

Simberloff D, Martin J-L, Genovesi P, Maris V, Wardle DA, Aronson J, Courchamp F, Galil B, García-Berthou E, Pascal M, et al. 2013. Impacts of biological invasions: what's what and the way forward. Trends Ecol Evol. (Amst.) 28:58-66.
Tamura K, Stecher G, Peterson D, Filipski A, Kumar S. 2013. MEGA6: Molecular Evolutionary Genetics Analysis version 6.0. Mol Biol Evol. 30:2725-2729.

Torres RA, Roper JJ, Foresti F, Oliveira C. 2005. Surprising genomic diversity in the Neotropical fish Synbranchus marmoratus (Teleostei: Synbranchidae): how many species? Neotrop Ichthyol. 3:277-284.

Utsunomia R, Pansonato Alves JC, Paiva LRS, Costa Silva GJ, Oliveira C, Bertollo LAC, Foresti F. 2014a. Genetic differentiation among distinct karyomorphs of the wolf fish Hoplias malabaricus species complex (Characiformes, Erythrinidae) and report of unusual hybridization with natural triploidy. J Fish Biol. 85:1682-1692.

Utsunomia R, Pansonato-alves JC, Costa-silva GJ, Mendonça FF, Scacchetti PC, Oliveira C, Foresti F. 2014b. Molecular and cytogenetic analyses of cryptic species within the Synbranchus marmoratus Bloch, 1795 (Synbranchiformes: Synbranchidae) grouping: species delimitations, karyotypic evolution and intraspecific diversification. Neotropical Ichthyol. 12:903-911.

Ward RD. 2009. DNA barcode divergence among species and genera of birds and fishes. Mol Ecol Resour. 9:1077-1085. 